\title{
THE INNOVATION THRESHOLD ${ }^{* * * *}$
}

\author{
BY \\ ERIK BROUWER*, TOM POOT** AND KEES VAN MONTFORT***
}

\begin{abstract}
Summary
This paper discusses a model for analysing the sales of new products. This model accounts for the fact that, even among those companies with permanent R\&D activities, a fraction of the firms did not have sales of innovative products over a two-year observation period. We propose a model in which the fixed costs of introduction are a major concern in the decision-making process. We apply a censored regression model, extended by a firm-specific threshold. We use a structural model to estimate the fixed costs of introducing new products to the market, and explain subsequent sales of innovative products. We examine an indicator of innovative output, i.e. the sales of products 'new to the firm'. We estimate fixed cost thresholds by using data from the Dutch section of the Community Innovation Survey (CIS) of 1998. R\&D intensity, competition, and market structure all have a positive impact on the sales of new products. The most important factors that reduce the fixed cost threshold of introduction are product-related R\&D investments, R\&D subsidies, and knowledge spillovers.
\end{abstract}

Key words: Innovation, product R\&D, threshold model

JEL classification: C51, L23, O30

\section{INTRODUCTION}

This paper originated from the empirical observation that even among firms that have R\&D as a permanent activity, a fraction of firms did not have sales of innovative products during a two-year observation period. The reason for not introducing new products might be a lack of capabilities needed to introduce new products, difficulties entering a market in which competitor innovations are protected by strong propriety rights Teece (1986)) which therefore acts as a barrier to entering a market with new or improved products, or firms might even wait and see whether a major change in product-market combination is actually accepted before introducing their own new products.

* Tilburg University, Tilburg, The Netherlands.

** Utrecht University, Utrecht, The Netherlands.

***VU University Amsterdam, Amsterdam, The Netherlands, e-mail: kvmontfort@feweb.vu.nl; Nyenrode Business University, Breukelen, The Netherlands.

**** We would like to thank Geert Ridder, Alfred Kleinknecht and two anonymous reviewers for their valuable comments and discussion. 
Waiting is often a sensible approach because firms that introduce innovations that do not meet with success spend a considerable amount of time and incur financial costs while commercializing the innovations, and may also damage their reputation among users.

An extension to the latter argument could be that not all firms are faced with the same intensity of product market competition (lack of necessity) or that firms have different strategies to respond to competition, for instance, by slightly modifying their existing product portfolio (i.e. incremental innovation) in order to keep up with the competition instead of developing new products. The latter might involve higher costs and economic risk, or the cost of introducing new products to the market will not be covered by subsequent sales. We elaborate on this argument in this paper. ${ }^{1}$

Within the general framework of the product life cycle, we propose a threshold model that includes the fixed costs of introduction as a major concern when deciding whether or not to introduce new products to the market (see among others Felder etal. (1996), Mairesse and Mohnen (2001)). This study analyses an indicator of a firm's innovative output, i.e. sales per employee of products that are 'new to the firm' as a response to competition, and the firm-specific cost structure. This indicator was first analysed in Brouwer and Kleinknecht (1996), who noted that, during the observation year, many firms had no sales of new products and proposed an ad hoc model to deal with those firms that had zero sales. One drawback to their procedure is that the estimates of the parameters have no clear interpretation.

In this study we assume that a firm must incur fixed costs in order to introduce a product innovation. When considering introducing a new product, the firm will compare fixed costs with expected (net) revenues over the economic lifetime of the product, and only if revenues exceed fixed costs, will the firm introduce the product. We show that this simple theoretical model will lead to a specific censored regression model, the stochastic threshold model. Moreover, it can be argued on theoretical grounds that variables that affect fixed costs do not have a direct effect on the level of sales. This suffices to identify the parameters of the threshold model. Although without making further assumptions, we cannot directly estimate fixed costs, we can identify determinants of the threshold and of the sales of innovative products. This is an improvement on the estimates obtained by Brouwer and Kleinknecht (1996), who did not make a distinction between the two equations. Their estimates are reduced-form estimates, whereas we present estimates that correspond to a structural model, and we allow an economic interpretation in the context of that model. Our research

1 In this study we leave aside the issue of the timing of investments. Fennema et al. (2006) found evidence of a two-year cycle of investment spikes. In this paper we concentrate on the decision whether or not to introduce new products onto the market. 
is also useful in connection with the protracted discussions in the Netherlands in recent years about how to promote innovations.

This paper is arranged as follows. In section 2 we discuss the main determinants of the threshold and the fixed costs equation, we introduce the theoretical model and describe the corresponding econometric model. Section 3 discusses our data. Section 4 presents our hypotheses. In Section 5 we present and discuss the outcomes of our estimates, and conclusions are drawn in section 6.

\section{SALES OF INNOVATIVE PRODUCTS WITH FIXED INTRODUCTION COSTS}

\subsection{Introduction}

Generally speaking, the market for new products, just like any other market, is determined predominantly by demand, supply and market conditions, in addition to other determinants such as institutional factors or long-term technological developments, which are beyond the scope of this paper. We are assuming that, in principle, individual firms are capable of adapting to changes in market conditions only by changing their own products, i.e. the firmspecific supply characteristics, and we assume demand factors as given. We will elaborate on the supply-side factors below.

Only very large firms are capable of moulding market conditions to their own interests, whereas the majority of smaller firms are forced to accept the market conditions as given. The situation is even more complicated when innovative products are introduced to the market. At company level, firms compete along product characteristic lines, price, quality and other factors specific to that particular firm or product. The joint outcome in competing on a more aggregate level implies technological development or technological opportunities and demand articulation, which can be understood by applying the theoretical ideas of the product life cycle model. ${ }^{2}$ This model states that the higher the pace of technological development, the more firms must invest in the development of new products, as old products are superseded by superior new ones

2 The model of the product life cycle brings together the combined effects of technological opportunities, dominant design, demand, entry and exit, the distribution of size of firms, and market conditions in time and builds on the work of Gort and Klepper (1982) and Klepper and Graddy (1990). See among others Jovanovic and MacDonald (1994) and Klepper and Simons (2000), Klepper (2002) for an empirical assessment. The notion of dominant design stems from Albernathy and Utterback (1978), Rosenberg (1982) and Sahal (1986). For a review of the notion of dominant design in economics see Nelson (1995). A different strand of literature points at the relationship between business cycles and innovation using the 'demand pull' and 'supply push' paradigm, and the associated controversy (see Schmookler (1996), Scherer (1982)). However, the causal effects of demand pull or supply push on innovative activities are not substantiated by empirical findings (Scherer (1982); Geroski and Walters (1995)). 
(from competing firms). In branches characterized by mature technology and modest opportunities for further technological development, firms are more likely to improve products on an incremental basis, and their earnings will stem predominantly from improved or unaltered products, though probably produced more cheaply as a result of cost-reducing process innovation.

There is also a direct relationship between the sales of innovative products and market structure and, implicitly, the average size of firms in a specific branch. According to the product life cycle, there are many small firms that compete in the first stages of technological development on design, and on combinations of product and market. In this situation the market structure manifests a low seller concentration. Later, when a specific combination of product and market dominates technological development, and when consumers are more inclined towards a particular design, firms have to abandon their unsuccessful product - market combinations in favour of a more successful competing design. Once a dominant design has been established, firms will start to compete on price and economies of scale become an important determinant in order to survive, which starts the 'oligopolistic shake-out'. Many firms that fail to achieve a minimum efficient production scale must sooner or later leave the market, which results in a market dominated by a few large firms competing on price (Klepper (1996)). However, firms facing Bertrand competition have a strong incentive to increase their profit margin through product differentiation, and will therefore reap more sales from new products if their products succeed in time (Martin (1993); Kaniovski (2005)).

On a micro level, small firms have a strong incentive to introduce new products into the market in order to create a niche market, in which they have to change in order to survive competition with current firms. On the other hand, large firms have an incentive to invest in both process (economies of scale) and product innovation (economies of scope) in order to maintain their market position (Cohen and Klepper (1996)). Based on this strand of literature, one could expect a (stylized) U-shaped relationship between the sales of new products and the seller concentration. This U-shape is also congruent with the Schumpeter Mark I and II relationships between the size of the firm and the incentive to innovate (Baumol (2002); Kamien and Schwartz $(1975,1982)$; Scherer $(1982,1992))$.

The relationship between competition and innovation recently became more puzzling. Aghion etal. (2005) have shown that an inverted U-shaped relationship between competition and innovation fits much better in UK panel data covering the period between 1973 and 1994, which challenges both empirical and theoretical findings of the traditional Industrial Organization (IO) literature. In their paper they present an alternative model, which boils down to different strategic, step-by-step product innovative behaviour in so-called levelled industries and neck and neck industries. The 'escape competition effect' increases the incremental profit from innovation, 
but the 'Schumpeterian effect' reduces innovation incentives for laggards as competition increases. "The balance between these two effects changes between low and high levels of competition, generating an inverted U-shaped relationship" (Aghion et al. (2005, pp. 720-721)).

What are the factors that affect the costs of introducing new innovative products into the market? Firms can implement several strategies to minimize the fixed costs of introduction. In this respect the role of knowledge spillovers is very important. Innovation is all about developing (technical) knowledge. In a seminal paper, Jaffe (1986, pp. 984) states: 'Since knowledge is inherently a public good, the existence of technologically related research efforts of other firms may allow a given firm to achieve results with less research effort than otherwise'. Therefore, firms that are actively seeking opportunities to exploit knowledge spillovers will have a competitive advantage, assuming those firms have enough absorptive capacity to make effective use of those knowledge spillovers.

Besides knowledge spillovers originating from (semi) public sources, suppliers and customers also serve as important sources of knowledge. According to Von Hippel (1988), it is not necessarily the inventor who develops the innovation. Instead, it is the actor in the vertical chain of product development (distributed innovation process) that has the best opportunity to manage the appropriability conditions who will be the innovator. We expect that firms that rely on information from suppliers and customers as sources of innovation have a better opportunity to appropriate the rents of innovation and to spend less on introducing new products (see among others Lilien et al. (2002)).

This paper examines a theoretical and empirical model based on Brouwer (1997). The theoretical model implies that the innovative product will be introduced if the (expected) sales exceed a certain threshold. We then specify an empirical model that corresponds to this theoretical model, and we show that the restrictions derived from the theoretical model are sufficient to identify the threshold, which we assume to be firm specific.

\subsection{The Theoretical Model}

In addition to the fixed costs of introduction, there may be other reasons for a firm with R\&D activities not having sales of innovative products in a particular year. The product may still be under development, or the firm may only have achieved process innovations. The latter were enquired about in a question requiring a 'yes' or 'no' response, without any sales related to it being assessed. We concentrate in our analysis on firms that engage permanently in R\&D, as opposed to occasionally, and that have developed new products in the recent past. Broader definitions of sample firms have also been tentatively used in our estimates but will not be documented in detail, since these analyses did not lead to substantially different 
outcomes. We assume that our firms with $\mathrm{R} \& \mathrm{D}$ activities can decide whether to introduce an innovative product in any year.

First we introduce the variables used in the model.

$s=\mathrm{R} \& \mathrm{D}$ spending;

$y=$ Annual sales of the innovative product;

$\mu=$ Expected annual sales of the innovative product;

$c=$ Fixed cost of introducing the innovative product;

$T=$ Economic lifespan of the innovative product;

$r=$ Discount rate;

$\gamma=$ Mark-up of the price over variable cost per unit.

Without loss of generality, we assume that all R\&D spending is made at time 0 , just before the decision to introduce the product. At that time the expected discounted return from the investment $s$ is

$$
\int_{0}^{T} \gamma \cdot \mu(s) \cdot e^{-r t} \cdot d t-s-c
$$

In practice $\mu$ can, of course, vary over time. We assume $\mu$ is constant over the economic lifespan. This approximation regarding $\mu$ is not restrictive, because in the theoretical model we will only deal with the total discounted sales of the innovative product over the economic lifespan. The integral of expression (1a) can be worked out:

$$
\frac{\gamma}{r} \cdot\left(1-e^{-r T}\right) \cdot \mu(s)-s-c
$$

We assume that R\&D spending $s$ has a positive effect on the expected sales of the innovative product. Given $s>0$, the first-order condition for a profit maximum is

$$
\frac{\gamma}{r} \cdot\left(1-e^{-r T}\right) \cdot \mu^{\prime}(s)=1
$$

If we assume that $\mu^{\prime \prime}(s)<0$ and $\mu^{\prime}(s)>0$, then the first-order equation has a finite solution. However, if there is no value of $s$ satisfying equation (2), then expression (1a) and (1b) decrease for every $s>0$, and the optimal R\&D investment will be equal to zero. We denote the optimal R\&D investment by $s^{\text {opt }}$. The optimal level of R\&D spending is independent of the fixed costs of introduction $c$. Furthermore, R\&D spending rises with $\gamma$, which is an index of competition. The stronger the competition, the lower the optimal R\&D spending. Unfortunately, we do not have an index of competition, or information about the mark-up. Instead, we use a Herfindahlindex as a proxy of 
competition. ${ }^{3}$ The optimal level also rises with $T$, and falls with $r$. In addition, we have no indicator of the economic lifespan of the innovative product at our disposal. This may seem an important omission in order to identify the proposed model. However, from an entrepreneurial point of view, future sales are unknown and the decision to introduce a new product into the market will depend on expected sales, which will depend on demand i.e. consumer preferences, product substitution and imitation, in short competition, which is already incorporated in the model. We will elaborate on supply, demand and market conditions below.

Note that $\mu(s)$ is the expected sales at the time that the level of R\&D spending is determined. In this model these expenditures on $R \& D$ are referred to as the current R\&D spending, which is the costs the entrepreneur is expected to recover from sales in order to distinguish from the R\&D spending in the past that can be considered a sunk cost, which, by definition, has no relevance in the decision-making process as to whether or not new products should be introduced into the market. When deciding whether or not to introduce the innovative product, the expected sales differ from their previously expected value by a prediction error $v$ and are equal to

$$
y=\mu\left(s^{\mathrm{opt}}\right)+v
$$

The innovation is introduced if, and only if, the expected discounted return exceeds the fixed cost of introduction

$$
\frac{\gamma \cdot\left(\mu\left(s^{\mathrm{opt}}\right)+v\right) \cdot\left(1-e^{-r \cdot T}\right)}{r}>c
$$

Equation (3) and inequality (4) specify a threshold regression model: if the expected revenues exceed the threshold costs (in inequality (4)) then sales are given in equation (3).

This simple theoretical model implies that the optimal level of R\&D spending and hence the expected sales of the new product, are independent of the cost of introduction. This does not mean that the R\&D effort is independent of the costs of introduction. If the expected costs of introduction are high, the project may be unprofitable, i.e. the expected discounted return in (1) may be negative, and the project will not be implemented. However, given the fact that a project is profitable, the optimal spending is independent of the fixed costs of introduction. This result is important for the specification of the threshold model, because it justifies the exclusion of variables that affect the fixed cost of introduction from the sales equation. It should be stressed that R\&D effort in

3 Strictly speaking a Herfindahlindex of concentration is not an equivalent of an index of competition. However, in line with the Structure-Conduct-Performance framework a concentration index can be regarded as a proxy of competition (Church and Ware (2000)). Creusen etal. (2006) present a recent discussion on the measurement of competition. 
our empirical model is an explanatory variable and not a dependent variable, i.e. we model the sales of innovative products given (past) R\&D effort.

\subsection{The Econometric Model}

For the specification of the econometric model that corresponds to equations (3) and (4), it is convenient to introduce some further notation:

$y=$ Observed annual sales of innovative products; (in the estimations we take the $\log$ in order to avoid heteroskedasticity);

$y^{*}=$ Latent annual sales of innovative products;

$c^{*}=$ Latent fixed threshold;

$x=$ Exogenous variables that influence the sales of innovative products;

$z=$ Exogenous variables that influence the threshold of sales of innovative products;

$\beta=$ Vector of regression coefficients of variables $x$;

$\alpha=$ Vector of regression coefficients of variables $z$;

$\varepsilon=$ Error term of sales equation;

$\eta=$ Error term of threshold equation;

$\sigma_{\varepsilon}=$ Standard deviation of $\varepsilon$;

$\sigma_{\eta}=$ Standard deviation of $\eta$;

$\rho=$ Correlation coefficient of $\varepsilon$ and $\eta$.

We do not attempt to estimate the structural model in (3) and (4) directly. From (4) we see that the threshold is

$$
c^{*}=\frac{c \cdot r}{\gamma \cdot\left(1-e^{-r \cdot T}\right)}<\left(\mu\left(s^{\mathrm{opt}}\right)+v\right)
$$

We express $c^{*}$ in (5) and $\mu\left(s^{\text {opt }}\right)$ in (3) as a function of exogenous variables $z$ and $x$, respectively. In the sequel, we use the exclusion restrictions of the economic model. In other words, variables that affect the threshold through the fixed cost $c$ do not enter the sales equation (3). Hence, we obtain the latent regression equations

$$
\begin{aligned}
& c^{*}=z \alpha+\eta \\
& y^{*}=x \beta+\varepsilon \\
& \left(\begin{array}{l}
\varepsilon \\
\eta
\end{array}\right) \sim N\left(\left(\begin{array}{l}
0 \\
0
\end{array}\right),\left(\begin{array}{ll}
\sigma_{\varepsilon}^{2} & . . \\
\rho \sigma_{\varepsilon} \sigma_{\eta} & \sigma_{\eta}^{2}
\end{array}\right)\right)
\end{aligned}
$$

Firms will have sales of new products if, and only if, the (expected) sales of the new product exceed the threshold $c^{*}$. Hence, the latent and observed 
variables are related by

$$
\begin{aligned}
& I=I\left(y^{*}>c^{*}\right) \\
& y=\left[\begin{array}{rr}
0 & \text { if } I=0 \\
y^{*} & \text { if } I=1
\end{array}\right]
\end{aligned}
$$

The probability of positive sales of a new product is

$$
\operatorname{Pr}(I=1)=\operatorname{Pr}\left(y^{*}>c^{*}\right)=\Phi\left(\frac{x \beta-z \alpha}{\sigma_{\eta^{*}}}\right)
$$

where $\sigma_{\eta^{*}}^{2}=\sigma_{\eta}^{2}+\sigma_{\varepsilon}^{2}-2 \rho \sigma_{\varepsilon} \sigma_{\eta}$ is the variance of $\eta^{*}=\eta-\varepsilon$, and $\phi$ is the cumulative distribution function of the standard normal distribution. The expected sales of the innovative product, conditional on the event that they are positive, are

$$
E(y \mid I=1)=x \beta+\frac{\sigma_{\varepsilon}^{2}}{\sigma_{\eta^{*}}^{2}} \frac{\varphi\left(\frac{x \beta-z \alpha}{\sigma_{\eta^{*}}}\right)}{\Phi\left(\frac{x \beta-z \alpha}{\sigma_{\eta^{*}}}\right)}
$$

where $\phi$ is the density function of the standard normal distribution (see Johnson and Kotz (1980)).

The likelihood function of the threshold model is derived from the joint distribution of the observed variables $(y, I)$

$$
\begin{aligned}
& f_{y, I}(I=0)=\operatorname{Pr}\left(y^{*}<c^{*}\right)=1-\Phi\left(\frac{x \beta-z \alpha}{\sigma_{\eta^{*}}}\right) \\
& \begin{aligned}
f_{y, I}(y, I=1) & =\operatorname{Pr}\left(c^{*}<y^{*} \mid y^{*}=y\right) \cdot f_{y^{*}}(y) \\
& =\Phi\left(\frac{(y-z \alpha)-\rho \cdot \sigma_{\eta}\left(\frac{y-x \beta}{\sigma_{\varepsilon}}\right)}{\sigma_{\eta} \sqrt{1-\rho^{2}}}\right) \cdot \frac{\varphi\left(\frac{y-x \beta}{\sigma_{\varepsilon}}\right)}{\sigma_{\varepsilon}}
\end{aligned}
\end{aligned}
$$

The loglikelihood can be used to estimate the unknown model parameters. It is also possible to estimate the model by a two-stage estimation method (see Maddala (1983, pp. 228-230)). We used the estimates of the two-stage method as starting values for the maximum likelihood estimation.

Nelson (1977, p. 315) and Maddala (1983, p. 229) discussed the identification of the parameters of the threshold model. A sufficient condition for identification is that the sales equation contains at least one exogenous variable that is not in the threshold equation. As noted before, variables that affect the threshold through the cost of introduction can be excluded from the sales equation, so that this condition can be easily satisfied. 


\section{THE DATA}

\subsection{Source and Background}

We used data from the Dutch section of the Community Innovation Survey (CIS) for 1994-1996 (CIS2) and 1996-1998 (CIS21/2, see CBS (1998, 2000)). The CIS data comprise firms in all sectors with 10 or more employees. We merged the two datasets in order to have information over a longer period of time, and in order to be able to construct lagged exogenous variables, which will be discussed later. ${ }^{4}$ Both questionnaires consisted of two parts. Firms were asked in the first part to give basic details about the firm, such as the branch of principal activity, sales, exports, employment, etc. The second part included questions on $\mathrm{R} \& \mathrm{D}$, innovation and related issues. Only firms that answered at least one of the following three questions in the affirmative were asked to complete the second part of the questionnaire:

- Did your firm develop any technologically changed products during 1996-1998?

- Did your firm develop any technologically changed processes during 1996-1998?

- Does your firm plan to develop any technologically changed products or processes in the years 1999-2001?

Firms that gave a positive answer to any of these questions in both questionnaires are defined as innovative.

A distinction is made in the survey between three types of product: (1) essentially unchanged products; (2) incrementally improved products, and (3) radically changed or totally new products. In this paper we refer to the last category as 'innovative products' and this is the subject of our analysis. A further distinction is made in the survey between:

- Products 'new to the firm';

- Products 'new to the market'.

Although it is tempting to use products 'new to the market' as an indicator of the most innovative products, here we use products 'new to the firm' as the endogenous variable, because the 'new to the market' indicator suffers from a serious problem in the way firms interpret their scope of the relevant market. For instance, are firms referring to the Dutch market, the European or the world market? Brouwer and Kleinknecht (1996) refer to the relationship between the export share of firms and the turnover from products 'new to the market', the higher the export share, the less turnover from products 'new to the market' they have. Therefore, it seems that firms, more oriented 
toward the home market which, in the case of the Dutch market, tends to be relatively small, are overestimating their innovative efforts. We restrict our analysis to sales 'new to the firm' in order to avoid this ambiguity.

\subsection{Descriptive Statistics}

The aim of our model is to capture innovation in manufacturing industries. We excluded firms in the service sector from the merged dataset. Firms were then selected according to the following criteria: presented in both questionnaires (CIS2 and CIS21/2), being innovative in 1994-1998, and with an R\&D output at least in 1996-1998. Finally, this selection resulted in a database of 2279 firms. A brief comparison of firms selected and those excluded from the sample show that small firms are under represented in the sample, and the selected firms have, on average, a higher export share (see the Appendix). We can distinguish two groups of firms within the sample of 2279 firms. The first group comprises 1002 innovative firms with turnover from innovative products in 1996-1998 as defined earlier. The second group consists of innovative firms without turnover from innovative products in 1996-1998. The latter group comprises of 1277 firms focusing on process innovations, or firms in the stage of developing new products that have not yet been introduced to the market.

The descriptive statistics for all the innovative firms are given in Table 1. Table 1 shows that the average turnover is 31 million Dutch Guilders or 16 million US Dollars. ${ }^{5}$ The difference in turnover between firms with and without turnover from innovative products is small and insignificant. Moreover, the number of employees does not differ significantly between the two groups of firms. The average size is about a 100 employees. The standard deviations of total turnover and the number of employees are quite large, because about $90 \%$ of all Dutch firms have 50 employees or less, but there are also a few large (multinational) companies in the sample that have high labour productivity and high sales of new products. This therefore reflects the very skewed distribution of the size of firms in the Netherlands. Because of this, and on theoretical grounds, on which we elaborate later, we will model size in a non-linear fashion. Innovative firms obtain, on average, about $13 \%$ of their turnover from the sale of innovative products, and $8.3 \%$ if weighted with the size of firms, meaning that larger firms have less turnover from new products.

The descriptive statistics of the variables for dataset 1 (all innovative firms), 2 (firms with turnover from new products) and 3 (firms without new

5 The Dutch guilder was replaced in 2000 by the euro. All the statistics before 2000 are in Dutch currency. In the year 1998 the average exchange rate was 1.9825 guilder for one US dollar (source Dutch National Bank, DNB). 
TABLE 1 - DESCRIPTIVE STATISTICS OF THE VARIABLES USED IN THE MODEL

$\begin{array}{lll}\text { (1) All } & \text { (2) Firms } & \text { (3) Firms } \\ \text { innovative } & \text { with } & \text { without } \\ \text { firms } & \text { turnover } & \text { turnover } \\ & \text { new } & \text { new } \\ & \text { products } & \text { products }\end{array}$

Mean Std.dev. Mean Std.dev. Mean Std.dev. Sig*

Dummy: $1=$ turnover form products new to the firm 1998

$\begin{array}{lllll}17.269 & 1.464 & 17.241 & 1.491\end{array}$

Log turnover from products new $6.487 \quad 7.423 \quad 14.754 \quad 1.818 \quad$ n/a $\quad$ n/a

to the firm 1998

Turnover from products new to $0.059 \quad 0.116 \quad 0.133 \quad 0.144 \quad \mathrm{n} / \mathrm{a} \quad \mathrm{n} / \mathrm{a}$

the firm as \% of total turnover 1998

Log number of employees (FTE) 1998

R\&D employment intensity 1996

$\%$ of total $\mathrm{R} \& \mathrm{D}$ spending which

have to be recovered 1996

Source of information: internal (score 0..1) 1996

Source of information: suppliers

or customers (score 0..1) 1996

Source of information: publicly

available information, proxy for

$\begin{array}{lll}0.440 & 0.496 & 1\end{array}$

0

knowledge spillovers (score 0..1)

1996

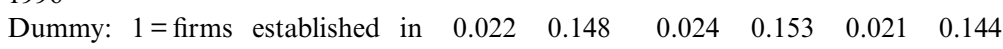

1994-1996

$\begin{array}{llllll}4.580 & 1.094 & 4.604 & 1.134 & 4.562 & 1.062\end{array}$

$\begin{array}{llllll}0.024 & 0.056 & 0.041 & 0.067 & 0.014 & 0.047\end{array}$

$\begin{array}{llllll}0.385 & 0.392 & 0.394 & 0.366 & 0.378 & 0.411\end{array}$

$\begin{array}{llllll}0.396 & 0.310 & 0.536 & 0.241 & 0.338 & 0.317\end{array}$

$\begin{array}{llllll}0.324 & 0.284 & 0.449 & 0.241 & 0.268 & 0.283\end{array}$

$\begin{array}{llllll}0.193 & 0.190 & 0.279 & 0.180 & 0.152 & 0.177\end{array}$

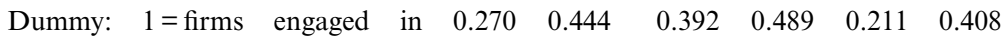

R\&D cooperation 1996

Dummy: $1=$ firms received sub-

sidies to stimulate technological

progress 1998

Observations

1002

1277

Difference between means of firms in dataset 2 and dataset 3: ***Significant at the $1 \%$ level, **Significant at the $5 \%$ level and *Significant at the $10 \%$ level. 
products) differ significantly, except for the following variables: turnover, the number of employees and the fraction of firms established in 1994-1996.

\section{SELECTION OF EXPLANATORY VARIABLES}

Before presenting the results, we formulate the hypotheses to be tested with our model. This allows us to identify variables that can be included or excluded from either the fixed cost equation or sales equation. We first deal with hypotheses regarding the sales equation, then we deal with the fixed cost equation.

\subsection{Determinants of Sales of New Products}

\section{$\mathrm{H1}: R \& D$ intensity and sales of new products}

Since R\&D expenditures are a major input in the innovation process, we expect a firm's R\&D intensity to be directly related to its 'output' of product innovations. $R \& D$ intensity is a proxy for firm-specific adaptation to market conditions and branch-specific technological change.

\section{H2: Competition/Market structure and sales of new products}

We argued in section 2 that the link between competition/market structure and innovation is a complicated one. Based on the product life cycle model and mainstream IO literature, we might expect a (stylized) U-shaped relationship between the sales of new products and the seller concentration, expressed as the Herfindahl-equivalent index. ${ }^{6}$ According to Aghion et al. (2005) we might expect an inverted U-shape relationship. In order to investigate the relationship between the sales of new products and the seller concentration, we include a Herfindahl-equivalent index and Herfindahl-equivalent index squared to capture the non-linear relationship. The coefficients will indicate which type of reasoning is appropriate.

\subsubsection{Other Factors}

The sample includes mature firms and newly established firms. We first have to correct for start-up firms because, by necessity, new or start-up firms only have sales of new products and no sales of improved or unaltered products. We therefore include a dummy in the sales equation, whether a firm is a startup-firm i.e. a firm established in the 1994-1996 period or not, in order to rectify this potential bias. We expect this dummy to have a positive effect on the level of sales. 


\subsection{Determinants of the Fixed Cost Equation}

\section{H3: Product related $R \& D$ investments and the fixed cost equation}

We expect that the more a firm has to spend on developing product-related R\&D activities, the higher the costs of introduction will be, which means that these costs have to be recouped. Awaiting the introduction of a new product into the market, we assume that firms will shift their total R\&D expenditures towards more product-related $\mathrm{R} \& \mathrm{D}$ expenditures, such as expenditures on the development of production facilities or specialized equipment, design and marketing and, apart from expenditures on fundamental or basic research according to the chain-linked model of innovation of Kline and Rosenberg (1986). The percentage of total R\&D investment spent on the introduction of new products serves as a proxy of costs directly related to the fixed cost of introducing new products. These costs differ from $\mathrm{R} \& \mathrm{D}$ expenditures in the pre-competitive phase of developing products, which can be considered as sunk costs. Sunk costs are, by definition, irrelevant in the decision-making process as to whether or not to introduce new products into the market.

H4: $R \& D$ co-operation and $R \& D$ subsidies lower the fixed costs of sales of new products

The sharing of knowledge and risks through R\&D co-operation agreements decreases the fixed cost of introduction of new products, besides enhancing future innovatory benefits by internalizing positive external effects (De Bondt (1996)). R\&D subsidies directly lower the fixed costs.

\section{H5: Knowledge spillovers and the fixed cost equation}

We expect that using external sources of knowledge, such as information from consultants, universities, patent-data, and other semi-public agencies, will lower the costs of R\&D or, more particularly, the fixed costs of introducing new products into the market. Furthermore, we expect that sources of information originating from suppliers and customers will have a downward effect on the fixed costs of introduction, compared with costs for firms that predominantly rely on internal knowledge. ${ }^{7}$

7 From the point of view of individual firms, a firm tends to focus on receiving knowledge spillovers and at the same time tries to avoid sending spillovers and thus creating positive appropriability conditions (Teece (1986)). CIS2 does not comprise direct information to distinguish between incoming (receiving) and outgoing (sending) knowledge spillovers, especially the measurement of outgoing knowledge spillovers is cumbersome (see Cassiman and Veugelers (2002), in an attempt to use proxies to distinguish between incoming and outgoing knowledge spillovers). 


\subsection{Other Exogenous Variables}

\section{H6: Size of firms and innovative products}

One important exogenous variable is the size of the firms, operationalized as the log of the number of employees. We expect the size of the firm to affect both the level of sales and the amount of investment required to introduce new products into the market. The larger the firm, the more resources are available to invest in introducing new products and, at the same time, larger firms are expected to have better market opportunities to realize sales of new products (economies of scope). This combined effect resembles the theory of 'spreading' introduced by Cohen and Klepper (1996) in order to explain why larger firms invest relatively more in $\mathrm{R} \& \mathrm{D}$, albeit with a lower efficiency compared with smaller firms. However, the situation is somewhat more complicated. On average, larger firms will have a larger product portfolio and, in order to prevent 'cannibalizing' their existing product portfolio, larger firms will be more reluctant to introduce new products into the market (Conner (1988)). We expect that size will have a non-linear effect on both the level of sales and on the fixed cost. Furthermore, we have included branch dummies in the cost equation in order to correct technology and/or branch specific costs of introduction.

One might argue that prior to introducing new products into the market, firms have to deal with all kinds of competitive effects between (competing) firms in the same market, and that those factors will influence the decisionmaking process. Unfortunately, we do not have any information about competing firms or competing products. CIS data only register the outcome of the decision-making process, whether firms have turnover from new products or not. We assume that firm-specific market conditions are incorporated in the decision-making process and are reflected in the fixed cost and will not induce biased estimates.

\section{RESULTS}

The estimates of the threshold model are summarized in Table 2 for products new to the firm. The threshold is not observed directly, but can be derived from the model by subtracting the costs of introduction from the sales. A positive coefficient in the costs equation means that the corresponding variable is positively related to the sales threshold. In other words, it increases the threshold. If the coefficient of a variable that is found in the costs equation and in the sales equation is positive, and if it is larger in the sales equation than in the threshold equation, then the variable increases the probability that the firm will innovate (see equation 11). The same is true if the coefficient in the sales equation is negative and smaller than in the threshold equation. 
TABLE 2 - THE ESTIMATION RESULTS

\begin{tabular}{|c|c|c|c|c|}
\hline \multirow[t]{2}{*}{ Exogenous variables } & \multicolumn{2}{|c|}{ Sales equation } & \multicolumn{2}{|c|}{ Fixed costs equation } \\
\hline & Coefficient & $t$-value & Coefficient & $t$-value \\
\hline Constant & 11.004 & $185.020^{* * *}$ & 10.699 & $170.853^{* * *}$ \\
\hline $\begin{array}{l}\text { Dummy: } 1=\text { firms established in } \\
\text { 1994-1996 }\end{array}$ & 0.337 & $5.524^{* * *}$ & & \\
\hline R\&D employment intensity 1996 & 1.670 & $25.652^{* * *}$ & & \\
\hline Log turnover 1998 & 0.813 & $28.214^{* * *}$ & 1.468 & $28.214^{* * *}$ \\
\hline $\begin{array}{l}\text { Log turnover 1998, squared (coeffi- } \\
\text { cient multiplied by 10) }\end{array}$ & 0.303 & $7.513^{* * *}$ & -0.231 & $7.513^{* * *}$ \\
\hline Herfindahl equivalent index & -0.195 & $-6.611^{* * *}$ & & \\
\hline $\begin{array}{l}\text { Herfindahl equivalent index squared } \\
\text { (coefficient multiplied by } 100 \text { ) }\end{array}$ & 0.237 & $7.414^{* * *}$ & & \\
\hline $\begin{array}{l}\% \text { of total } \mathrm{R} \& \mathrm{D} \text { spending which have } \\
\text { to be recovered } 1996\end{array}$ & & & 0.134 & $2.360^{* *}$ \\
\hline $\begin{array}{l}\text { Dummy: } 1=\text { firms engaged in } \\
\text { co-operation } 1996\end{array}$ & & & -0.036 & -0.649 \\
\hline $\begin{array}{l}\text { Dummy: } 1=\text { firms received subsidies } \\
\text { to stimulate technological progress } \\
1998\end{array}$ & & & -1.017 & $-17.997^{* * *}$ \\
\hline $\begin{array}{l}\text { Source of information: internal (score } \\
\text { 0..1) } 1996\end{array}$ & & & -0.466 & $-7.621^{* * *}$ \\
\hline $\begin{array}{l}\text { Source of information: suppliers or } \\
\text { customers (score 0..1) 1996 }\end{array}$ & & & -0.475 & $-7.740^{* * *}$ \\
\hline $\begin{array}{l}\text { Source of information: publicly availa- } \\
\text { ble information, proxy for knowledge } \\
\text { spillovers (score 0..1) } 1996\end{array}$ & & & -1.117 & $-17.444^{* * *}$ \\
\hline $\begin{array}{l}\text { Dummy: } 1=\text { Pavitt taxonomy, Scale- } \\
\text { intensive industrial firms } \#\end{array}$ & & & -1.244 & $-21.515^{* * *}$ \\
\hline $\begin{array}{l}\text { Dummy: } 1=\text { Pavitt taxonomy, Specia- } \\
\text { lized equipment suppliers } \#\end{array}$ & & & -1.139 & $-18.844^{* * *}$ \\
\hline No. obs. & 2279 & & & \\
\hline Log likelihood & -2892.82 & & & \\
\hline Log likelihood base-line model & -3583.59 & & & \\
\hline LR test & 1381.54 & & & \\
\hline Mc Fadden $R^{2}$ & 0.19 & & & \\
\hline Zimmerman-Veal $R^{2}$ & 0.50 & & & \\
\hline
\end{tabular}

***Significant at the $1 \%$ level, **Significant at the $5 \%$ level and

*Significant at the $10 \%$ level. ${ }^{\#}$ Adopted from Pavitt (1984). 
Even though the threshold is not being observed, the parameters of the threshold equation and those of the sales equation are identified by exclusion restrictions. The theoretical model in section 2.2 implies that variables that affect the fixed costs can be excluded from the sales equation. For that reason, a variable such as $R \& D$ collaboration or product introductory related $\mathrm{R} \& \mathrm{D}$ expenditures does not enter the sales equation. We do allow for correlation between the error terms in the threshold and sales equations. This correlation captures common firm-specific variables that have been omitted from both equations.

We now go on to discuss the parameter estimates in Table 2, starting with the effect of size on both the fixed costs and sales, then the parameter estimates of the sales equation and, lastly, the parameter estimates of the fixed costs equation.

Size

As we expected, larger firms realize higher sales of new products. Larger firms benefit from economies of scale and scope and therefore have the production and marketing capacity to achieve higher sales of new products. Smaller firms are forced to focus on niche markets, which are smaller by definition, and therefore the potential to realize sales of new products is also smaller.

\subsection{Parameter Estimates of the Sales Equation}

Table 2 shows that new firms have indeed a significantly higher percentage of sales of new products, which confirms that the inclusion of newly-established firms could introduce a bias in the estimations.

A higher R\&D intensity results in higher sales of new products. This is consistent with the theoretical model in section 2 and hypothesis 1 above.

The effect of market structure measured by a Herfindahl-equivalent index on the sale of new products, departs from hypothesis 2. Instead of a U-shape, we find a non-linear negative relationship (convex) between the seller concentration and sales of new products, meaning that markets with a lower seller concentration i.e. dominated by relatively small firms, generate more turnover from new products. Our empirical result is congruous with most empirical work on the relationship between competition and innovation (see Nickell (1996)), and this finding agrees with the Schumpeter Mark I theory (Schumpeter (1934)) and Arrow's replacement effect, which restrain large companies from investing seriously in product innovations (Arrow (1962)). However, this result does not fully comply with the proposed Schumpeterian and product life cycle models, as discussed in section 2, which predict a U-shaped relationship between innovative activities and market structure. 


\subsection{Parameter Estimates of the Fixed Costs Equation}

\subsubsection{Product Related $R \& D$ Investments}

Hypothesis 3 states that there is a positive relationship between product related $R \& D$ expenditures as a percentage of total $R \& D$ investments and the fixed costs, which have to be recouped from the sales of new products. The parameter estimate confirms this hypothesis showing a positive and significant coefficient. We also stated that, according to economic theory, sunk costs do not have any significance in deciding on investments such as R\&D expenditures at the introduction of new products into the market.

\subsection{2 $R \& D$ Collaboration and $R \& D$ Subsidies}

In accordance with hypothesis $4, R \& D$ collaboration and subsidies reduce the fixed costs of introduction, although the effect of $\mathrm{R} \& \mathrm{D}$ collaboration is insignificant. A major $R \& D$ policy instrument in the Netherlands is a general tax-credit facility to lower the labour costs of $\mathrm{R} \& \mathrm{D}$ personnel, entitled the WBSO ${ }^{8}$ The purpose of the WBSO is to reduce the R\&D costs of firms, in particular those of SMEs. Large firms are bound to a maximum of tax credits. Subsidies, including the WBSO, reduce the costs of introducing new products into the market. One could argue that the effect of the WBSO is not entirely exogenous. Firms anticipating the introduction of new products may have an incentive to apply.

One possible explanation for not finding a significant effect of collaboration on the fixed costs might be that, besides a cost-reducing motive to be engaged in $R \& D$ collaboration, there could also be a skill-sharing motive, such as to develop and share new knowledge, different fields of technology or different markets (Sakakibara (1997)). The collaborative efforts could be focused on applied knowledge for specific products competing on the market (non-collusive R\&D cooperation) or geared towards more basic knowledge in order to strengthen the innovative skills of the collaborators on a basic level and in an early phase of the innovation cycle. In the latter case, the effect of $R \& D$ co-operation will not have a significant effect on the fixed costs. We do not have any additional information to disentangle the two effects, but the estimates seem to indicate that the skill-sharing type of $R \& D$ collaboration is predominant and thus mitigates the cost reducing effect of $\mathrm{R} \& \mathrm{D}$-cooperation on fixed costs.

\subsubsection{Knowledge Spillovers}

Table 2 shows that the intensive use of numerous different sources of information significantly decreases the fixed costs. The estimated coefficients show

8 WBSO is an acronym of the Dutch name of the act to encourage R\&D (Wet Bevordering Speur-en Ontwikkelingswerk). 
that knowledge spillovers have the strongest effect, and the use of internal knowledge the weakest effect. In line with Jaffe (1986), this result shows that innovating firms benefit most from overall knowledge spillovers. The question is how these findings should be interpreted. Jaffe (1986) argues that knowledge spillovers reflect the technological opportunities that exist in a particular branch. Technological opportunities are an incentive for product development and a signal that product differentiation is a profitable strategy. If a particular branch has few technological opportunities, the amount of research needed to come up with something new will be higher compared with a branch with an abundance of technological opportunities. According to Jaffe's reasoning, it is not primarily the knowledge itself but rather its signalling effect that is important. This would explain why the other sources of knowledge are also important, besides general knowledge spillovers. The estimates of coefficients of sources of internal information and information regarding suppliers or customers show that relying on one's own technological strength or being involved in a distributed product development, as exposed by Von Hippel (1988), appear to be equally effective.

We performed a number of simulations to improve our understanding of the implications of the estimates. For that purpose we define a reference firm that resembles the average firm in our sample. In the simulations we change one exogenous variable at a time and consider its effect on the sales threshold, the sales per employee of innovative products, and the probability of an innovative product being introduced. The reported importance of a continuous independent variable is calculated as the difference between the effect corresponding to the basic value of this variable plus the standard deviation, and the effect corresponding to the basic value of this variable minus the standard deviation. The effect of an independent dummy variable is obtained by the difference between the situation in which the dummy variable is equal to 1 and the situation in which the dummy variable is equal to 0 .

Subsidies are one of the most important factors to decrease the threshold. On average, the granting of subsidies reduces the threshold by more than 2.7 million euros. The probability of introducing a new product will increase by $25 \%$.

According to the estimated coefficients, the relationship between competition and innovation is U-shaped, particularly when we looked at the coefficients of number of employees and the Herfindahl-equivalent index. We concluded that the smaller and larger firms are more likely to innovate. And we could then say that Schumpeter (1934) was right, after all. The small firms are the real innovators (Mark I) and if they are not innovative then the larger firms will be the innovators (Mark II). According to the simulation we see a slightly different picture - the curve is not a complete U-shaped curve. We see that the smaller firms are the most innovative firms, and the probability of being innovative diminishes with size. We also see that the slope will diminish, but the curve will not increase. That means that there is more 
TABLE 3 - THE EFFECTS OF THE INDEPENDENT VARIABLES ON THE SALES OF NEW PRODUCTS, THE THRESHOLD FOR NEW PRODUCTS AND THE PROBABILITY OF A NEW PRODUCT BEING INTRODUCED

\begin{tabular}{|c|c|c|c|}
\hline Exogenous variables & $\begin{array}{l}\text { Sales } \\
\text { (thousand } \\
\text { Euros) }\end{array}$ & $\begin{array}{l}\text { Threshold } \\
\text { (thousand } \\
\text { Euros) }\end{array}$ & $\begin{array}{l}\text { Probability } \\
\text { of intro- } \\
\text { duction } \\
(\%)\end{array}$ \\
\hline Dummy: 1 = firms established in 1994-1996 & 100 & 0 & 1 \\
\hline R\&D employment intensity 1996 & 230 & 0 & 3 \\
\hline Log number of employees $1998^{*}$ & 5,330 & 10,060 & -9 \\
\hline Log number of employees 1998 , squared & & & \\
\hline $\begin{array}{l}\text { Herfindahl equivalent index* } \\
\text { Herfindahl equivalent index squared }\end{array}$ & -740 & 0 & -102 \\
\hline $\begin{array}{l}\% \text { of total } \mathrm{R} \& \mathrm{D} \text { spending that has to be } \\
\text { recovered } 1996\end{array}$ & 0 & 290 & -3 \\
\hline $\begin{array}{l}\text { Dummy: } 1=\text { firms engaged in co-operation } \\
1996\end{array}$ & 0 & -100 & 1 \\
\hline $\begin{array}{l}\text { Dummy: } 1=\text { firms received subsidies to sti- } \\
\text { mulate technological progress } 1998\end{array}$ & 0 & $-2,760$ & 25 \\
\hline $\begin{array}{l}\text { Source of information: internal (score 0..1) } \\
1996\end{array}$ & 0 & -810 & 7 \\
\hline $\begin{array}{l}\text { Source of information: suppliers or custo- } \\
\text { mers (score } 0 . .1 \text { ) } 1996\end{array}$ & 0 & -760 & 7 \\
\hline $\begin{array}{l}\text { Source of information: publicly available } \\
\text { information, proxy for knowledge spillovers } \\
\text { (score 0..1) } 1996\end{array}$ & 0 & $-1,200$ & 10 \\
\hline $\begin{array}{l}\text { Dummy: } 1=\text { Pavitt taxonomy, Scale-intensive } \\
\text { industrial firms }\end{array}$ & 0 & $-1,850$ & 18 \\
\hline $\begin{array}{l}\text { Dummy: } 1=\text { Pavitt taxonomy, Specialized } \\
\text { equipment suppliers }\end{array}$ & 0 & $-1,160$ & 11 \\
\hline
\end{tabular}

*Total effect of the non-linear function

empirical evidence for Mark I than for Mark II. With our model and the indicators we use for innovation and competition, we do not see an inverse U-curve like Aghion et al. (2005) found in the UK.

Internal information, suppliers or customers' information and publicly available information are very important for firms, but these sources are slightly less important than information from competitors and information from universities and GTIs. The threshold will diminish by around 1 million euros and the probability of introducing a new product will increase by between $7 \%$ and $10 \%$. 
Firms in the scale-intensive sector or specialized equipment suppliers, will have a lower threshold and a higher probability of introducing a new product than the other remaining sectors.

Finally, we would like to state that the fit of our threshold model is rather good. The Zimmerman Veal $R^{2}$ and the Mc Fadden $R^{2}$ are 0.50 and 0.19, respectively. The value of the logarithm of likelihood of the threshold model and the corresponding baseline model are -2892 and -3583 , respectively.

\section{SUMMARY AND CONCLUSIONS}

In this paper, we have put forward a model to analyse the sales of new products. This model accounts for the fact that, even among firms that have permanent R\&D activities, a fraction of firms do not have sales of innovative products over a two-year observation period. We analyse an indicator of a firm's innovative output 'new to the firm'. The firm must incur fixed costs in order to introduce a product innovation. When considering the introduction of a new product, the firm will compare fixed costs with expected (net) revenues over the economic lifetime of the product, and only if revenues exceed fixed costs (threshold) will the firm introduce the product.

Our results show that firms face a threshold when deciding whether or not to introduce new products into the market. The fixed costs of introduction are an obstacle to the introduction of new products. Firms focus on means to lower these costs. Factors that are important to decrease the fixed costs include knowledge spillovers and $R \& D$ related subsidies. It is not surprising that $R \& D$ related subsidies decrease the fixed costs. More interesting, however, are the differences between knowledge spillovers and sources of information and their effect on the fixed costs. These differences reveal much about the know-how of management strategies in innovating firms. In general, spillovers of public knowledge have a profound effect on the fixed costs, but interestingly, knowledge spillovers originating from the firm itself (technology initiator) or from suppliers and customers (technology follower) have an equally decreasing effect on the fixed costs, albeit a lower one. The results show that both strategies of technology initiator and technology follower appear to be equally effective, which endorses the view of a distributed innovation process, as exposed by Von Hippel (1988).

Our results also substantiated the idea that $R \& D$ expenditures, such as expenditures on developing production facilities or specialized equipment, design and marketing, are an important element in the decision-making process whether or not to introduce new products onto the market, according to the chain-linked model of Kline and Rosenberg (1986). The level of sales of new products depends on the R\&D intensity and market structure, once more substantiating the Schumpeter Mark I paradigm and the Arrow replacement effect, meaning that small (high-tech) firms are more important to 
commercialize innovative products, partially substantiating the product life cycle model of Cohen and Klepper (1996).

\section{APPENDIX: DATA PREPARATION AND SELECTION}

The presence of lagged exogenous variables in the model poses extra demands on the dataset. We used two questionnaires to create a dataset with lagged variables. The first one is the regular Dutch CIS questionnaire comparable with the Eurostat version, which comprises data for the period 1994-1996. It is the policy of Statistics Netherlands to repeat the CIS questionnaire after 2 years. This 'in between' questionnaire, covering the period 1996-1998, is identical to the Eurostat version, although extended with some additional questions, which are of no concern for the purpose of this paper.

The initial dataset was created by merging the Dutch CIS2 (1994-1996) and CIS21/2 (1996-1998) questionnaires. Of the database of 10996 firms, three groups of firms were excluded: firms in the service sector, firms without any innovative activity according to the Frascati manual, and firms that were found in only one period. After excluding these firms, a database remained consisting of 2278 firms, which leaves us with information covering the years 1994-1998. We used the 2278 firms to analyse the innovation threshold, of which 1001 firms with sales from new products and 1277 firms without sales, i.e. firms assumed not to be able to meet the threshold requirements.

The main question is whether the 2278 firms used in our analysis are representative of all firms. In order to analyse this potential selection bias, we compared the mean values of four firm indicators among the various selections presented earlier. The indicators are: (1) the number of employees, and (2) turnover in 1998, representing different aspects of the size of the firms involved. The other two indicators are: (3) the turnover per employee, representing a kind of 'productivity' measure, and (4) the export share, representing a competition measure. Firms with a higher export share are expected to face stronger competition because they are operating on a world market, while firms with a lower export share are stepping up towards the domestic market. Of course the four indicators are broad indicators, solely made up for the purpose of identifying a possible selection bias, and not for a serious analysis of firm characteristics. The characteristics of the four indicators and the results of a $t$-test as to whether the means are statistically different from each other, are presented in the table below.

Table A1 shows that the firms that were excluded from the main database are, on average, significantly smaller, both in terms of the number of employees and in terms of turnover. The turnover per employee does not differ significantly, but the firms that were excluded have, on average, a significantly lower export share. This selection bias can be explained by the sampling procedure Statistics Netherlands applies. Due to the very skewed 
distribution of firm size, $82 \%$ of all firms in the Netherlands have $10-50$ employees, a random selection of $18 \%$ of the firms with $10-50$ employees received a CIS questionnaire, while all firms with 50 or more employees received our questionnaire. In merging the two datasets (CIS2 and CIS2 $1 / 2$ ) small firms are less likely to be selected in both CIS questionnaires $(3 \%=$ $0.18^{*} 0.18$ ), and we selected only those firms that were included in both questionnaires, resulting in a selection bias. In other words, merging two CIS questionnaires and selecting firms included in both questionnaires will favour the larger firms (i.e. 50 employees and more). This is reflected in the results of Table A1, showing that the selected firms, included in both questionnaires are, on average, larger.

Secondly, we investigated whether there are differences between firms with or without sales of new products. Table A2 shows the results. Size is no longer a discriminating factor in the population of selected firms. However, turnover per employee and the export share differ significantly between the two sub-

TABLE A1 - CHARACTERISTICS OF FOUR FIRM INDICATORS: NUMBER OF EMPLOYEES, TURNOVER, TURNOVER PER EMPLOYEE, AND EXPORT SHARE IN 1998 AFTER MERGING CIS2 AND CIS $2 \frac{1}{1} 2$

\begin{tabular}{|c|c|c|c|c|}
\hline $\begin{array}{l}\text { Whole data base } \\
\text { (CIS } 2 \text { and } \text { CIS } 2^{1} / 2 \\
\text { merged) }\end{array}$ & $\begin{array}{l}\text { Number of } \\
\text { employees (fte) } \\
1998\end{array}$ & $\begin{array}{l}\text { Turnover } \\
1998(\times 1000 \\
\text { guilders })\end{array}$ & $\begin{array}{l}\text { Turnover } \\
(\times 1000 \\
\text { guilders }) \text { per } \\
\text { employee } \\
(1998) \\
(3)\end{array}$ & $\begin{array}{l}\text { Export share } \\
1998\end{array}$ \\
\hline \multicolumn{5}{|l|}{ All firms } \\
\hline Mean & 131.47 & 66138.55 & 521.216 & $11.3 \%$ \\
\hline Std error mean & 7.05 & 3473.37 & 31.973 & 0.002 \\
\hline \multicolumn{5}{|l|}{$\begin{array}{l}\text { Firms not selected } \\
\text { ( } 8718 \text { observations })\end{array}$} \\
\hline Mean & 106.65 & 49263.96 & 518.463 & $8.6 \%$ \\
\hline Std error mean & 7.46 & 2656.46 & 39.378 & 0.002 \\
\hline \multicolumn{5}{|l|}{$\begin{array}{l}\text { Firms selected ( } 2278 \\
\text { observations) }\end{array}$} \\
\hline Mean & 226.44 & 130734.40 & 531.752 & $21.5 \%$ \\
\hline Std error mean & 18.44 & 13249.91 & 33.320 & 0.007 \\
\hline \multicolumn{5}{|l|}{$\begin{array}{l}\text { t-test: selected versus } \\
\text { not selected firms }\end{array}$} \\
\hline Diff & -119.79 & -81470.42 & -13.289 & $-12.9 \%$ \\
\hline Std err & 19.89 & 13513.58 & 51.583 & 0.007 \\
\hline$t$-value & -6.023 & -6.029 & -0.258 & -17.938 \\
\hline Prob $>|t|$ & 0.0000 & 0.0000 & 0.7967 & 0.0000 \\
\hline
\end{tabular}


TABLE A2 - CHARACTERISTICS OF FOUR FIRM INDICATORS: NUMBER OF EMPLOYEES, TURNOVER, TURNOVER PER EMPLOYEE, AND EXPORT SHARE IN 1998 RESTRICTED TO THE POPULATION OF FIRMS MEETING ALL SELECTION CRITERIA

\begin{tabular}{|c|c|c|c|c|}
\hline Selected firms & $\begin{array}{l}\text { Number of } \\
\text { employees (fte) } \\
1998 \\
\text { (1) }\end{array}$ & $\begin{array}{l}\text { Turnover } \\
1998(\times 1000 \\
\text { guilders })\end{array}$ & $\begin{array}{l}\text { Turnover } \\
(\times 1000 \\
\text { guilders) per } \\
\text { employee } \\
\text { (1998) } \\
(3)\end{array}$ & $\begin{array}{l}\text { Export share } \\
1998\end{array}$ \\
\hline $\begin{array}{l}\text { Firms without tur- } \\
\text { nover new products } \\
\text { ( } 1277 \text { observations) }\end{array}$ & & & & \\
\hline Mean & 227.44 & 119672.90 & 623.736 & $10.6 \%$ \\
\hline $\begin{array}{l}\text { Std error mean } \\
\text { Firms with turnover } \\
\text { new products (1001 } \\
\text { observations) }\end{array}$ & 29.870 & 17679.830 & 56.261 & 0.007 \\
\hline Mean & 225.17 & 144831.80 & 414.405 & $35.3 \%$ \\
\hline $\begin{array}{l}\text { Std error mean } \\
\text { t-test: firm with ver- } \\
\text { sus without turnover } \\
\text { new products }\end{array}$ & 17.580 & 20013.620 & 23.993 & 0.011 \\
\hline Diff & 2.27 & -25158.90 & 209.332 & $-24.7 \%$ \\
\hline Std err & 34.66 & 26704.33 & 61.164 & 0.013 \\
\hline$t$-value & 0.066 & -0.942 & 3.422 & -18.810 \\
\hline Prob $>|t|$ & 0.9477 & 0.3462 & 0.0006 & 0.0000 \\
\hline
\end{tabular}

populations, albeit in different directions. Firms with turnover from new products have, on average, a lower turnover per employee but a higher export share.

Open Access This article is distributed under the terms of the Creative Commons Attribution Noncommercial License which permits any noncommercial use, distribution, and reproduction in any medium, provided the original author(s) and source are credited.

\section{REFERENCES}

Aghion, P., N. Bloom, R. Blundell, R. Griffith and P. Howitt (2005), 'Competition and Innovation: An Inverted U Relationship,' The Quarterly Journal of Economics, 120-122, pp. 701-728. 
Albernathy, J.M. and J.M. Utterback (1978), 'Patterns of Industrial Innovation,' Technology Review, 41-7, pp. 2-9.

Arrow, K.J. (1962), 'Economic Welfare and the Allocation of Resources for Invention,' in: R.R. Nelson (ed.) The Rate and Direction of Inventive Activity: Economic and Social Factors, Princeton University Press for the NBER.

Baumol, W.J. (2002), The Free Market Innovation Machine: Analysing the Growth Miracle of Capitalism, Princeton, Princeton University Press.

Brouwer, E. (1997), 'Into Innovation: Determinants and Indicators,' PhD Dissertation, University of Amsterdam, The Netherlands.

Brouwer, E. and A.H. Kleinknecht (1996), 'Determinants of Innovation: A Micro Econometric Analysis of Three Alternative Innovation Output Indicators,' in: A. Kleinknecht (ed.) Determinants of Innovation. The Message from New Indicators, London, Macmillan Press, pp. 99-124.

Cassiman, B. and R. Veugelers (2002), 'R\&D Cooperation and Spillovers: Some Empirical Evidence from Belgium,' American Economic Review, 92, pp. 1169-1184.

CBS (1998), Kennis en Economie 1998, Statistics Netherlands, Voorburg/Heerlen, CBS.

CBS (2000), Kennis en Economie 2000, Statistics Netherlands, Amsterdam, Elsevier bedrijfsinformatie.

Church, J. and R. Ware (2000), Industrial Organization, A Strategic Approach, Boston, Irwin McGraw-Hill.

Cohen, W.M. and S. Klepper (1996), 'A Reprise of Size and R\&D,' The Economic Journal, 106437, pp.925-951.

Conner, K.R. (1988), 'Strategies for Product Cannibalism,' Strategic Management Journal, 9, pp. 9-26.

Creusen, H., B. Minne and H. van der Wiel (2006), Does competition stimulate innovation and productivity in Dutch retail trade? De Economist, 154, pp. 429-441.

De Bondt, R. (1996), 'Spillovers and Innovative Activities,' International Journal of Industrial Organization, 15, pp. 1-28.

Felder, J., G. Licht, E. Nerlinger and H. Stahl (1996), 'Factors Determining R\&D and Innovation Expenditure in German Manufacturing Industries,' in: A. Kleinknecht (ed.) Determinants of Innovation, The Message from New Indicators, London, Macmillan Press.

Fennema, J., W. Letterie and G. Pfann (2006), 'The Timing of Investment Episodes in the Netherlands,' De Economist, 154, pp. 373-388.

Geroski, P.A. and C.F. Walters (1995), 'Innovative Activity Over the Business Cycle,' Economic Journal, 105, pp. 916-928.

Gort, M. and S. Klepper (1982), 'Time Path in the Diffusion of Product Innovations,' Economic Journal, 92, pp. 630-653.

Jaffe, A.B. (1986), 'Technological Opportunity and Spillovers of R\&D: Evidence from Firms' Patents, Profits, and Market Value,' The American Economic Review, 76-75, pp. 984-1001.

Johnson, N.L. and S. Kotz (1980), Distributions in Statistics: Continuous Multivariate Distributions, New York, Wiley.

Jovanovic, B. and G.M. MacDonald (1994), 'The Life Cycle of a Competitive Industry,' The Journal of Political Economy, 102-102, pp. 322-347.

Kamien, M.I. and N.L. Schwartz (1975), 'Market Structure and Innovation: A Survey,' Journal of Economic Literature, 13-11, pp. 1-37.

Kamien, M.I. and N.L. Schwartz (1982), Market Structure and Innovation, Cambridge, Cambridge University Press. 
Kaniovski, S. (2005), 'Product Differentiation and Competitive Selection,' Journal of Evolutionary Economics, 15, pp. 567-580.

Klepper, S. (1996), 'Entry, Exit, Growth, and Innovation over the Product Life Cycle,' The American Economic Review, 86-83, pp. 562-583.

Klepper, S. (2002), 'Firm Survival and the Evolution of Oligopoly,' The RAND Journal of Economics, 33-31, pp. 37-61.

Klepper, S. and E. Graddy (1990), 'The Evolution of New Industries and the Determinants of Market Structure,' Rand Journal of Economics, 21, pp. 24-44.

Klepper, S. and K.L. Simons (2000), 'The Making of an Oligopoly: Firm Survival and Technological Change in the Evolution of the U.S. Tire Industry,' The Journal of Political Economy, 108-104, pp. 728-760.

Kline, S.J. and N. Rosenberg (1986), 'An Overview of Innovation,' in: R. Landau and N. Rosenberg (eds.) The Positive Sum Strategy: Harnessing Technology for Economic Growth, Washington, National Academy Press, pp. 275-307.

Lilien, G.L., P.D. Morrison, K. Searls, M. Sonnack and E. von Hippel (2002), 'Performance Assessment of the Lead User Idea-Generation Process for New Product Development,' Management Science, 48-48, pp. 1042-1059.

Maddala, G.S. (1983), Limited-Dependent and Qualitative Variables in Econometrics, Cambridge, Cambridge University Press.

Mairesse, J. and P. Mohnen (2001), 'To Be or Not to be Innovative: An Exercise in Measurement,' NBER-Working Paper 8644.

Martin, S. (1993), Advanced Industrial Economics, London, Blackwell.

Nelson F.D. (1977), 'Censored Regression Models with Unobserved, Stochastic Censoring Thresholds,' Journal of Econometrics, 6, pp. 309-327.

Nelson, R.R. (1995), 'Recent Evolutionary Theorizing About economic Change,' Journal of Economic Literature, 33-31, pp. 48-90.

Nickell, S.J. (1996), 'Competition and Corporate Performance,' Journal of Political Economy, 104104, pp. $724-746$.

Pavitt, K. (1984), 'Sectoral Patterns of Technological Change: Towards a Taxonomy and a Theory,' Research Policy, 13, pp. 343-373.

Rosenberg, N. (1982), Inside the Black Box: Technology and Economics, Cambridge, Cambridge University Press.

Sahal, D. (1986), Patterns of Technological Innovation, Reading Mass., Addison-Wesley.

Sakakibara, M. (1997), 'Heterogeneity of Firm Capabilities and Cooperative Research and Development: An Empirical Examination of Motives,' Strategic Management Journal, 18, Summer Special Issue, pp. 143-164.

Scherer, F.M. (1967), 'Market Structure and the Employment of Scientists and Engineers,' American Economic Review, 57, pp. 524-531.

Scherer, F.M. (1982), 'Demand-Pull and Technological Invention: Schmookler Revisited,' Journal of Industrial Economics, 30, pp. 225-237.

Scherer, F.M. (1992), 'Schumpeter and Plausible Capitalism,' Journal of Economic Literature, 30, pp. 1416-1433.

Schmookler, J. (1966), Invention and Economic Growth, Cambridge, Harvard University Press.

Schumpeter, J.A. (1934), The Theory of Economic Development, Cambridge (Mass), Harvard Economic Studies. 
Teece, D.J. (1986), 'Profiting from Technological Innovation: Implications for Integration, Collaboration, Licensing and Public Policy,' Research Policy, 15, pp. 285-305.

Von Hippel, E. (1988), The Sources of Innovation, New York/Oxford, Oxford University. 